Шляхтіна Ганна Володимирівна викладач Інституту вищої кваліфікації, Київський національний торговельно-економічний університет, вул. Російська, 35, м. Київ, 02099, тел.: (066) 718-54-26, e-mail: chumakova_3@ukr.net, https://orcid.org/0000-0003-4134-8209

\title{
МЕХАНІЗМ РОЗВИТКУ ЛІДЕРСЬКОГО ПОТЕНЦАЛУ ДЕРЖАВНОГО СЛУЖБОВЦЯ
}

Анотація. У статті розглянуто шляхи реалізації державної політики України у сфері державної служби на основі формування дієвої системи розвитку лідерського потенціалу. Методичною базою дослідження є звіти щодо виконання Стратегій державної кадрової політики на 2012-2020 роки, сталого розвитку «Україна - 2020», реформування державного управління України на період до 2021 року, а також інформаційні та статистичні матеріали Національного агентства України 3 питань державної служби. Проведено аналіз впровадження основних напрямів реформування системи професійного навчання державних службовців, запровадження у сфері публічного управління сучасних інструментів управління персоналом, компетенцій трансформаційного лідерства, що передбачено для керівних посад державної служби.

На основі існуючих нормативно-правових актів доведено, що лідерство $\epsilon$ складовою профілю компетентності керівних посад державної служби. Також підтверджено, що керівникам сфери публічного управління недостатньо на сьогодні мати тільки професійні компетентності. Наразі управлінцям нової генерації потрібен розвиток комплексу відповідних навичок, використовуючи при цьому існуючі особистісні риси й установки, усвідомлення та мотивацію до дій. Розвиток лідерського потенціалу керівників усіх рівнів, особливо вищої керівної ланки, які мають бути відповідальними, свідомими та спроможними впроваджувати зміни у процесі здійснення системних реформ, $є$ одним 3 головних стратегічних завдань сфери публічного управління.

Зроблено висновки про те, що в Україні на сьогодні існує певна нормативно-правова база щодо розвитку лідерського потенціалу державних службовців, який здійснюється за визначеними напрямами. Підкреслено, що вказаний процес реалізується тільки за одним окремим вектором професійне навчання. Запропоновано здійснення системного визначення та періодичного перегляду навичок і компетенцій, необхідних для забезпечення належного їх поєднання з урахуванням зміни характеру роботи на державній службі, а також створення чіткого механізму розвитку лідерського потенціалу державного службовця та впровадження його законодавчо на державному рівні. 
Ключові слова: лідерський потенціал, публічне управління, професійні компетентності, реформа державного управління, управління людськими ресурсами.

Shlyakhtina Hanna Volodymyrivna Lecturer of the Institute of Higher Qualification, Kyiv National University of Trade and Economics, Rosiyska St., 35, Kyiv, 02099, tel.: (066) 718-54-26, e-mail: chumakova_3@ukr.net, https://orcid.org/0000-0003-4134-8209

\title{
MECHANISM FOR DEVELOPING THE POTENTIAL OF A CIVIL SERVANT LEADER
}

\begin{abstract}
The article considers the ways of realization of the state policy of Ukraine in the sphere of civil service on the basis of formation of effective system of development of leadership potential. The methodological basis of the study is reports on the implementation of the Strategies of State Personnel Policy for 20122020, sustainable development "Ukraine - 2020", public administration reform in Ukraine until 2021, as well as information and statistical materials of the National Agency of Ukraine for Civil Service. An analysis of the implementation of the main directions of reforming the system of professional training of civil servants, the introduction of modern tools for personnel management in public administration, the competencies of transformational leadership, which is provided for senior positions in the civil service.

Based on the existing regulations, it is proved that leadership is a component of the competence profile of senior civil service positions. It is also confirmed that it is not enough for public administration managers to have only professional competencies today. Currently, new generation managers need to develop a set of relevant skills, using existing personality traits and attitudes, awareness and motivation to act. Developing the leadership potential of managers at all levels, especially senior management, who must be responsible, aware and able to implement changes in the process of systemic reforms, is one of the main strategic objectives of public administration.

It is concluded that in Ukraine today there is a certain regulatory framework for the development of leadership potential of civil servants, which is carried out in certain areas. It is emphasized that this process is implemented only in one separate vector - vocational training. It is proposed to systematically define and periodically review the skills and competencies needed to ensure their proper combination, taking into account changes in the nature of work in the civil service, as well as creating a clear mechanism for developing the leadership potential of civil servants and implementing it at the state level.
\end{abstract}

Keywords: leadership potential, public administration, professional competencies, public administration reform, human resources management.

Постановка проблеми. Незважаючи на ключові досягнення реформи публічного управління 2019-2021 років, основними проблемами 
функціонування державної служби та управління людськими ресурсами на державній службі в Україні на сьогодні залишаються: низький рівень мотивації та відповідальності за результати своєї діяльності серед державних службовців, у тому числі серед керівників усіх рівнів; більшість центральних органів виконавчої влади не застосовують сучасні інструменти управління людськими ресурсами та професійного навчання, не враховують актуальні для кожної окремої організації стилі лідерства; відсутній достатній рівень професійних знань у сфері добору та розвитку персоналу на посадах державної служби.

Враховуючи вказане, актуальними завданнями на сьогодні є: побудова професійної, доброчесної, політично нейтральної й орієнтованої на громадян державної служби; запровадження та підтримка системи відбору на керівні посади державної служби на основі прозорості та відповідності найкращим практикам; забезпечення залучення найбільш професійних, компетентних та вмотивованих фахівців-лідерів до сфери публічного управління та притягнення їх до відповідальності за результати діяльності; прийняття на законодавчому рівні механізму розвитку лідерського потенціалу державних службовців.

Аналіз останніх досліджень і публікацій. Актуальні й значимі питання, пов'язані з розвитком лідерства у сфері публічного управління, висвітлені в працях таких дослідників, як: Н.Т. Гончарук (управління керівним персоналом у сфері державної служби України), І.М.Грищенко (теоретикометодологічні засади формування та розвитку лідерства в системі місцевого самоврядування), Н.С.Орлова (підготовка фахівців з публічного управління в умовах євроінтеграції України), а також у рекомендації ОЕСР щодо лідерства та спроможності державної служби (2019).

Метою статті $є$ удосконалення теоретичних та практичних рекомендації щодо формування механізму розвитку лідерського потенціалу державних службовців в умовах реформування публічного управління.

Виклад основного матеріалу. Формування та раціональне використання кадрів в публічному управлінні $\epsilon$ важливим i актуальним завданням реформи державного управління. Національне агентство України 3 питань державної служби (НАДС) забезпечує реалізацію державної політики щодо формування дієвої системи державного управління 3 професійними, доброчесними, етичними державними службовцями, які будують свою діяльність на лідерських засадах.

Забезпечення стабільної, результативної, справедливої діяльності органів державного управління, враховуючи покладені на них завдання, повноваження, компетенції, для створення умов розвитку громадянського суспільства, захисту свобод та прав громадянин, є головними завданнями та цілями державної служби.

Визначення та формулювання поняття «лідерство», рекомендації керівникові щодо поведінки для здійснення лідерства в органах державного управління вперше 3'явилось в офіційному документі - Указі Президента України від 1 лютого 2012 року № 45/2012 в контексті реалізації завдань 
стратегії державної кадрової політики на 2012-2020 роки [1].

Стратегією сталого розвитку «Україна - 2020», затвердженою Указом Президента України від 12 січня 2015 року № 5/2015, визначено головні напрями реформування державної служби з метою фіксації для кандидатів на державну службу більш високих вимог (наприклад, рівень лідерського потенціалу) [2]. Відповідно до зазначених стратегічних документів завданням Програми діяльності Кабінету Міністрів Україні, затвердженої 14 квітня 2016 року, також стала реформа публічної адміністрації, запровадження чітких та зрозумілих середньострокових стратегій міністерств, показників оцінки ефективності їхньої діяльності. Вона включає напрями реформування системи професійного навчання державних службовців, запровадження в системі державної служби сучасних інструментів управління персоналом, визначає орієнтири розвитку лідерства [3].

Реалізація однієї з ключових цілей реформ, визначених Стратегією приведення державної служби до сталого розвитку, обумовила прийняття нового Закону України «Про державну службу», який набув чинності 31 травня 2016 р. Прийняття закону стало рушійною силою в напрямку модернізації управління на державній службі, створення на ній нових векторів розвитку лідерства [4].

Прийняття Стратегії реформування державної служби та служби в органах місцевого самоврядування в Україні на період до 2017 року та плану заходів щодо іiі реалізації, затверджених розпорядженням Кабінету Міністрів України від 18 березня 2015 року № 227-р, стали ще однією важливою складовою щодо формування ефективної системи управління людськими ресурсами на державній службі та службі в органах місцевого самоврядування, що базується на врахуванні знань, умінь, навичок, а також особистісних якостей державних службовців та посадових осіб місцевого самоврядування, а також лідерського потенціалу державної служби та підвищення іiї інституційної спроможності [5].

У Стратегії реформування визначено мету, головні проблеми галузі, індикатори реформи державної служби, напрямки реалізації реформування для розвитку служби в органах місцевого самоврядування та державної служби в цілому відповідно до вимог Європейського співтовариства 3 атомної енергії і їхніми державами-членами, Свропейського Союзу, Угоди про асоціацію між Україною, Стратегії сталого розвитку «Україна 2020» [6].

Формування ефективної системи управління людськими ресурсами в органах місцевого самоврядування та на державній службі 3 урахуванням навичок, умінь, особистісних якостей, знань, посадових осіб місцевого самоврядування та державних службовців, що сприятимуть формуванню корпусу лідерів-управлінців, є одним з головних напрямків Стратегії.

Переважна кількість нормативно-правових актів, що забезпечують реалізацію вимог Закону України «Про державну службу» розроблена Національним агентством України з питань державної служби. Для посади 
державної служби категорії «А» передбачено наступні компетенції трансформаційного лідерства: управління проектами; управління змінами (оцінка ефективності змін, формування плану покращень та змін; управління реакцією на зміни); управління персоналом та організацією (контроль та організація роботи, мотивування, управління якісним обслуговуванням; управління людськими ресурсами); наявність лідерських навичок (встановлення пріоритетів, орієнтирів, цілей; стратегічне планування; ведення ділових переговорів; здатність виконувати одночасно декілька завдань; вміння працювати 3 великим обсягом інформації; досягнення кінцевих результатів). Зазначені компетенції визначені постановою Кабінету Міністрів України від 22 липня 2016 року № 448, яка затвердила Типові вимоги до осіб, які претендують на зайняття посад державної служби [7].

Наказом Національного агентства України з питань державної служби від 04 червня 2020 року № 94-20 визначено спеціальні вимоги для посадових осіб, які перебувають на посаді категорії «Б» i «В» державної служби» (таблиця 1) [8].

Таблиця 1

Форма вимог до осіб, які претендують на зайняття посад державної служби категорії «Б» (спеціальні вимоги) (на основі [8])

\begin{tabular}{|l|l|}
\hline 1.Професійні знання & $\begin{array}{l}\text { Відповідно до посади з урахуванням вимог } \\
\text { спеціальних законів }\end{array}$ \\
\hline 2.Лідерство & $\begin{array}{l}\text { 1) вміння обгрунтувати власну позицію } \\
\text { 2) досягнення кінцевих результатів }\end{array}$ \\
\hline $\begin{array}{l}\text { 3.Прийняття } \\
\text { ефективних рішень }\end{array}$ & $\begin{array}{l}\text { 1) вміння вирішувати комплексні завдання; } \\
\text { 2) встановлення цілей, пріоритетів та орієнтирів }\end{array}$ \\
\hline $\begin{array}{l}\text { 4.Коммунікації та } \\
\text { взаємодія }\end{array}$ & $\begin{array}{l}\text { 1) вміння ефективної комунікації та публічних } \\
\text { виступів } \\
\text { 2) співпраця та налагодження ефективної взаємодії }\end{array}$ \\
\hline $\begin{array}{l}\text { 5.Впровадження } \\
\text { змін }\end{array}$ & $\begin{array}{l}\text { 1) реалізація плану дій та покращень; } \\
\text { 2) здатність підтримувати зміни та працювати } \\
\text { реакцією на них; }\end{array}$ \\
\hline $\begin{array}{l}\text { 6.Управління } \\
\text { організацією роботи } \\
\text { та персоналом ефективності здійснення змін }\end{array}$ & $\begin{array}{l}\text { 1) організація і контроль роботи } \\
\text { 2) оцінка і розвиток підлеглих; }\end{array}$ \\
\hline $\begin{array}{l}\text { 7.Особистісні } \\
\text { компетенції }\end{array}$ & $\begin{array}{l}\text { 1) аналітичні здібності; } \\
\text { 2) інноваційність та креативність; } \\
\text { 3) вміння працювати в стресових ситуаціях }\end{array}$ \\
\hline
\end{tabular}

Отже, лідерство є складовою профілю компетентності посад категорії «Б». Такі посади, як заступники голів місцевих державних адміністрацій; керівники апаратів місцевих та апеляційних судів, керівники структурних підрозділів апаратів судів, їх заступники; керівники структурних підрозділів 
органів виконавчої влади, міністерств, інших державних органів, їх заступники, керівники структурних підрозділів, їх заступники, територіальних органів; керівники структурних підрозділів Секретаріату Кабінету Міністрів України, їх заступники належать до посад категорії «Б» відповідно до Закону України «Про державну службу».

Закон України «Про запобігання корупції» [9], наказ Національного агентства України з питань державної служби «Про затвердження Загальних правил етичної поведінки державних службовців та посадових осіб місцевого самоврядування» [10] акцентують увагу та визначають компетенції державних службовців, виконання яких забезпечить високі моральні якості та етику поведінки на державній службі. До того ж, наявність інтерактивної системи обміну інформацією лідерів-комунікаторів та зацікавлених сторін сприяють динамічному, універсальному та ефективному підходу до політики, що має відображати не просто політику уряду, але й національний наратив, схвалений у суспільстві [11].

Одним із зобов’язань, яке взяла на себе Україна відповідно до Угоди, є подальше удосконалення відповідно до стандартів ЄС системи підготовки та підвищення кваліфікації фахівців, тобто оволодіння державними службовцями та посадовими особами місцевого самоврядування новими професійними компетентностями, європейським досвідом реформування адміністративного управління та державної служби, інструментами досягнення комплексності і системності в управлінні, досвідом попередження соціальних, політичних, економічних конфліктів та ризиків. Тільки фахівці 3 відповідними навичками та знаннями в сфері державної політики можуть здійснювати процес проведення євроінтеграційних реформ та управління змінами [12].

Для розбудови країни, потрібна професійна державна служба, що є основою державного управління. За стратегічним планом діяльності на 20202023 роки НАДС зазначає стратегічні цілі та шляхи їх реалізації. Стратегічна ціль 4 визначає підвищення рівня професійної компетентності державних службовців, посадових осіб місцевого самоврядування, голів місцевих державних адміністрацій, їх перших заступників [13].

У реалізації зазначеної цілі пропонується низка завдань щодо розвитку професійних компетентностей державних службовців різних категорій на різних рівнях управління:

1. Запровадження дієвої системи визначення потреб у професійному навчанні державних службовців, посадових осіб місцевого самоврядування, голів місцевих державних адміністрацій, їх перших заступників i заступників, депутатів місцевих рад;

2. Створення належних умов для забезпечення професійного розвитку державних службовців, голів місцевих державних адміністрацій, їх перших заступників та заступників, посадових осіб місцевого самоврядування, депутатів місцевих рад;

3. Забезпечення безперервності, обов'язковості, плановості 
професійного навчання державних службовців, голів місцевих державних адміністрацій, їх перших заступників та заступників, посадових осіб місцевого самоврядування, депутатів місцевих рад;

4. Запровадження механізму співпраці державних органів, органів місцевого самоврядування, інститутів громадянського суспільства, програм міжнародної технічної допомоги, всеукраїнських асоціацій органів місцевого самоврядування, установ, закладів різних форм власності, що надають освітні послуги [14].

Отже, нормативно-правова база України стосовно розвитку лідерства посадових осіб органів державної влади сформовано за окремими напрямами. Однак, професійне навчання $є$ поки що основним напрямком розвитку лідерства у державних службовців. Діяльність щодо розвитку лідерського потенціалу державних службовців повинна бути затверджена на законодавчому рівні, де було б чітко регламентовано процес реалізації та пошуку можливостей розвитку лідерських компетентностей посадових осіб органів державної влади. [15]. Створення ефективного механізму для розвитку лідерського потенціалу державних службовців з боку держави $\epsilon$ необхідною умовою реалізації реформи публічного управління на місцях (рис. 1).

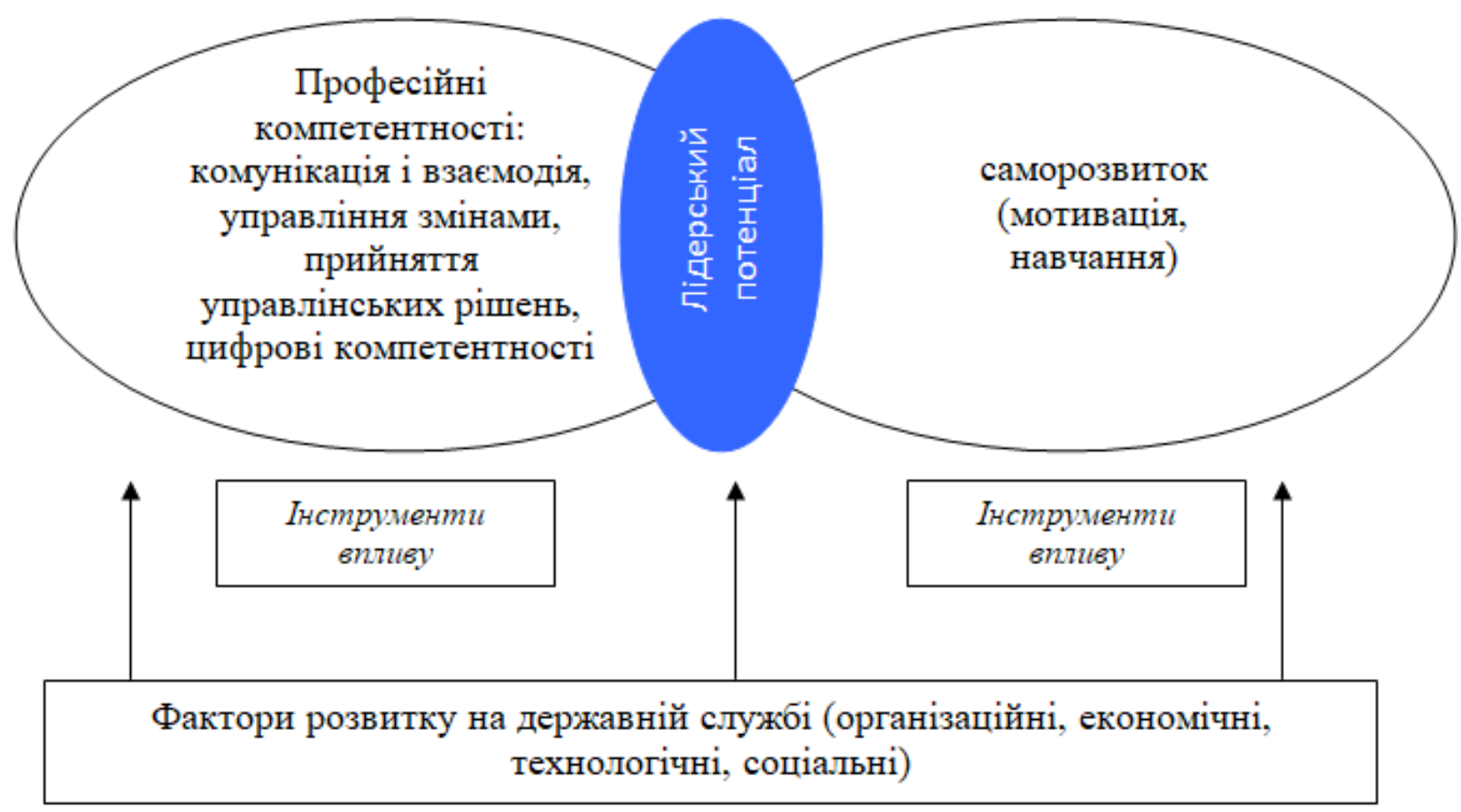

Puс.1. Механізм розвитку лідерського потенщіалу державних службовиів

Держава повинна створити всі умови для покращення розвитку лідерських якостей державних службовців та визначати ефективні інструменти впливу для створення продуктивного середовища на державній службі. Покращенню та розвитку лідерського потенціалу на державній 
службі могли б також сприяти залучення державних службовців до пошуку нових шляхів та заходів вирішення стратегічних проблем організації, можливості мобільності та запозичення нового досвіду в оцінці та прийняті управлінських рішень.

Висновки. В Україні на сьогодні існує певна нормативно-правова база щодо розвитку лідерського потенціалу державних службовців, який здійснюється за визначеними напрямами. Однак, вказаний процес реалізується тільки за одним окремим вектором - професійне навчання. Тому вбачаємо за потрібне:

- здійснювати системне визначення та періодичний перегляд навичок i компетенцій, необхідних для забезпечення належного їх поєднання 3 урахуванням зміни характеру роботи на державній службі;

- узгодження процесів управління людьми з визначеними навичками та компетенціями;

- розвиток необхідних навичок та компетенцій шляхом створення відповідного механізму розвитку лідерського потенціалу;

- створення культури навчання та середовища на державній службі, зокрема, шляхом визначення розвитку співробітників як основного управлінського завдання кожного державного менеджера та заохочення використання повних наборів навичок працівників; ініціативи.

- оцінку, нагородження та визнання результативності, таланту та

\section{Лimepamypa:}

1. Про Стратегію державної кадрової політики на 2012-2020 роки: Указ Президента України від 1 лютого 2012 року № 45/2012. https://zakon.rada.gov.ua/laws/show/45/2012\#Text.

2. Про Стратегію сталого розвитку «Україна - 2020»: Указ Президента України від 12 січня 2015 року № 5/2015 // Офіційний вісник Президента України. - 2015. - № 2. - с. 14.

3. Про Програму діяльності Кабінету Міністрів України: постанова Верховної Ради України від 14 квітня 2016 року № 1099-VIII. https://zakon.rada.gov.ua/laws/show/109919\#Text.

4. Про державну службу: Закон України від 10 грудня 2015 року № 889-VIII. https://zakon.rada.gov.ua/laws/show/889-19.

5. Про схвалення Стратегії реформування державної служби та служби в органах місцевого самоврядування в Україні на період до 2017 року та затвердження плану заходів щодо іiі реалізації: розпорядження Кабінету Міністрів України від 18 березня 2015 № 227 http://search.ligazakon.ua/l_doc2.nsf/link1/KR150227.html.

6. Стратегія реформування державного управління України на період до 2021 року, схвалена розпорядженням Кабінету Міністрів України від 24 червня 2016 р. № 474 (в редакції розпорядження Кабінету Міністрів України від 18 грудня 2018 року № 1102-р). https://zakon.rada.gov.ua/laws/show/474-2016-\%D1\%80\#Text.

7. Про затвердження Типових вимог до осіб, які претендують на зайняття посад державної служби категорії «А»: постанова Кабінету Міністрів України від 22 липня 2016 року №448. https://zakon.rada.gov.ua/laws/show/448-2016-\%D0\%BF\#Text.

8. Методичні рекомендації щодо визначення спеціальних вимог до осіб, які претендують на зайняття посад державної служби категорій «Б» і «В»: наказ Національного агентства України з питань державної служби № 4-21 від 15 січня 2021 року. https://nads.gov.ua/npas/pro-zatverdzhennya-metodichnih-rekomendaciyi-shchodo-viznachennyaspecialnih-vimog-do-osib-yaki-pretenduyut-na-zajnyattya-posad-derzhavnoyi-sluzhbi-kategorij-b-i-v. 
9. Про запобігання корупції: Закон України № 1700-VII від 14.10.2014. http://zakon3.rada.gov.ua/laws/show/1700-18.

10. Про затвердження Загальних правил етичної поведінки державних службовців та посадових осіб місцевого самоврядування: наказ Національного агентства України 3 питань державної служби від 05 серпня 2016 року № 158. https://zakon.rada.gov.ua/laws/show/z1203-16\#Text.

11. Орлова Н.С., Майло В.В. Розвиток стратегічних комунікацій в органах публічної влади. Вчені записки Таврійського національного університету імені В.І. Вернадського. Томі 31 (70) № 1, 2020. С.63-68

12. Детермінанти розвитку публічного управління та адміністрування в Україні: колективна монографія /за заг. ред. Н.С. Орлової. - Київ: ВД «Освіта України», 2020. $262 \mathrm{c}$

13. Стратегічний план діяльності НАДС на 2021-2023 роки. https://nads.gov.ua/storage/app/sites/5/plan-st.pdf.

14. План діяльності Національного агентства України з питань державної служби на 2021 рік. https://nads.gov.ua/storage/app/sites/5/nads-2021-2-25.pdf

15. Орлова Н. Підготовка фахівців 3 публічного управління в умовах євроінтеграції України // Науковий журнал «Зовнішня торгівля: економіка, фінанси, право». - 2019. - № 3 (104).

\section{References:}

1. Ukaz Prezydenta Ukrainy "Pro Stratehiiu derzhavnoi kadrovoi polityky na 2012-2020 roky” : vid 1 liutoho 2012 roku № 45/2012 [Decree of the President of Ukraine "On the Strategy of the state personnel policy for 2012-2020" from February 1 2012, № 45/2012]. zakon.rada.gov.ua. Retrieved from https://zakon.rada.gov.ua/laws/show/45/2012\#Text [in Ukrainian].

2. Ukaz Prezydenta Ukrainy "Pro Stratehiiu staloho rozvytku "Ukraina - 2020" : vid 12 sichnia 2015 roku № 5/2015 [Decree of the President of Ukraine "On the Strategy of Sustainable Development "Ukraine - 2020" from January 12 2015, № 5/2015]. (2015). Ofitsiinyi visnyk Prezydenta Ukrainy - Official Bulletin of the President of Ukraine, 2, 14 [in Ukrainian].

3. Postanova Verkhovnoi Rady Ukrainy "Pro Prohramu diialnosti Kabinetu Ministriv Ukrainy" : vid 14 kvitnia 2016 roku, № 1099-VIII [Resolution of the Verkhovna Rada of Ukraine "On the Program of Activities of the Cabinet of Ministers of Ukraine” from April 14 2016, № 1099-VIII]. zakon.rada.gov.ua. Retrieved from https://zakon.rada.gov.ua/laws/show/1099-19\#Text [in Ukrainian].

4. Zakon Ukrainy "Pro derzhavnu sluzhbu": vid 10 hrudnia 2015 roku № 889-VIII [Law of Ukraine "On Civil Service" from December 10 2015, № 889-VIII]. zakon.rada.gov.ua. Retrieved from https://zakon.rada.gov.ua/laws/show/889-19 [in Ukrainian].

5. Rozporiadzhennia Kabinetu Ministriv Ukrainy "Pro skhvalennia Stratehii reformuvannia derzhavnoi sluzhby ta sluzhby $\mathrm{v}$ orhanakh mistsevoho samovriaduvannia $\mathrm{v}$ Ukraini na period do 2017 roku ta zatverdzhennia planu zakhodiv shchodo yii realizatsii" : vid 18 bereznia 2015, № 227 [Order of the Cabinet of Ministers of Ukraine "On approval of the Strategy for reforming the civil service and service in local self-government in Ukraine for the period up to 2017 and approval of the action plan for its implementation" from March 18 2015, № 227]. search.ligazakon.ua. Retrieved from http://search.ligazakon.ua/1_doc2.nsf/link1/KR150227.html [in Ukrainian].

6. Rozporiadzhennia Kabinetu Ministriv Ukrainy "Stratehiia reformuvannia derzhavnoho upravlinnia Ukrainy na period do 2021 roku” : vid 24 chervnia 2016 r., № 474 [Order of the Cabinet of Ministers of Ukraine "Strategy of public administration reform of Ukraine for the period up to 2021" from June 24 2016, № 474]. zakon.rada.gov.ua. Retrieved from https://zakon.rada.gov.ua/laws/show/474-2016-\%D1\%80\#Text [in Ukrainian].

7. Postanova Kabinetu Ministriv Ukrainy "Pro zatverdzhennia Typovykh vymoh do osib, yaki pretenduiut na zainiattia posad derzhavnoi sluzhby katehorii «A»" : vid 22 lypnia 2016 roku 
№ 448 [Resolution of the Cabinet of Ministers of Ukraine "On approval of the Standard requirements for persons applying for civil service positions of category "A"' from July 222016 , № 448]. zakon.rada.gov.ua. Retrieved from https://zakon.rada.gov.ua/laws/show/448-2016$\%$ D0\%BF\#Text [in Ukrainian].

8. Nakaz Natsionalnoho ahentstva Ukrainy z pytan derzhavnoi sluzhby "Metodychni rekomendatsii shchodo vyznachennia spetsialnykh vymoh do osib, yaki pretenduiut na zainiattia posad derzhavnoi sluzhby katehorii «B» $\mathrm{i}$ «V»" : vid 15 sichnia 2021 roku, № 4-21 [Order of the National Agency of Ukraine for Civil Service "Methodical recommendations for determining special requirements for persons applying for civil service positions of categories "B" and "C"' from January 15, 2021, № 4-21]. nads.gov.ua. Retrieved from https://nads.gov.ua/npas/prozatverdzhennya-metodichnih-rekomendaciyi-shchodo-viznachennya-specialnih-vimog-do-osibyaki-pretenduyut-na-zajnyattya-posad-derzhavnoyi-sluzhbi-kategorij-b-i-v [in Ukrainian].

9. Zakon Ukrainy "Pro zapobihannia koruptsii" : vid 14.10.2014, № 1700-VII [Law of Ukraine "On prevention of corruption" from 14.10.2014, № 1700-VII]. zakon.rada.gov.ua. Retrieved from http://zakon3.rada.gov.ua/laws/show/1700-18 [in Ukrainian].

10. Nakaz Natsionalnoho ahentstva Ukrainy $\mathrm{z}$ pytan derzhavnoi sluzhby "Pro zatverdzhennia Zahalnykh pravyl etychnoi povedinky derzhavnykh sluzhbovtsiv ta posadovykh osib mistsevoho samovriaduvannia" : vid 05 serpnia 2016 roku, № 158 [Order of the National Agency of Ukraine for Civil Service "On approval of the General rules of ethical conduct of civil servants and local government officials” from August 5 2016, № 158]. zakon.rada.gov.ua. Retrieved from https://zakon.rada.gov.ua/laws/show/z1203-16\#Text [in Ukrainian].

11. Orlova, N.S., Mailo, V.V. (2020). Rozvytok stratehichnykh komunikatsii v orhanakh publichnoi vlady [Development of strategic communications in public authorities]. Vcheni zapysky Tavriiskoho natsionalnoho universytetu imeni V.I. Vernadskoho - Scientific notes of Tavriya National University named after VI Vernadsky, 31(70), 1, 63-68 [in Ukrainian].

12. Orlovoi N.S. (Eds.). (2020). Determinanty rozvytku publichnoho upravlinnia ta administruvannia $v$ Ukraini [Determinants of development of public administration and administration in Ukraine]. Kyiv: VD «Osvita Ukrainy» [in Ukrainian].

13. Stratehichnyi plan diialnosti NADS na 2021-2023 roky [Strategic plan of NAPS activity for 2021-2023]. nads.gov.ua. Retrieved from https://nads.gov.ua/storage/app/sites/5/plan-st.pdf [in Ukrainian].

14. Plan diialnosti Natsionalnoho ahentstva Ukrainy z pytan derzhavnoi sluzhby na 2021 rik [Activity plan of the National Agency of Ukraine for Civil Service for 2021]. nads.gov.ua. Retrieved from https://nads.gov.ua/storage/app/sites/5/nads-2021-2-25.pdf [in Ukrainian].

15. Orlova, N. (2019). Pidhotovka fakhivtsiv z publichnoho upravlinnia v umovakh yevrointehratsii Ukrainy [Training of specialists in public administration in the context of European integration of Ukraine]. Zovnishnia torhivlia: ekonomika, finansy, pravo - Foreign Trade: Economics, Finance, Law, 3(104), 139-150 [in Ukrainian]. 